ORIGINAL ARTICLE

\title{
ASSOCIATION OF PPARA INTRON 7 G/C (RS4253778) POLYMORPHISMS WITH MUSCULAR ENDURANCE AMONG SOCCER SCHOOL STUDENTS IN MEDAN
}

\author{
Roy Wilson Sihaloho ${ }^{1,4}$, Yahwardiah Siregar ${ }^{2,4}$, Maya Savira $^{3}$ \\ ${ }^{1}$ Darmo Nursing Academy Medan \\ ${ }^{2}$ Department of Biochemistry, Faculty of Medicine, University of North Sumatra, Medan \\ ${ }^{3}$ Department of Physiology, Faculty of Medicine, University of North Sumatra, Medan \\ 4 Master of Biomedical Sciences Study, Faculty of Medicine, University of North Sumatera, \\ Medan \\ *Corresponding author: kentzu.3103@gmail.com
}

\begin{abstract}
Peroxisome proliferator-activated receptor alpha (PPAR $\alpha$ ) is the transcription-factor gene that regulates lipid metabolism and glucose homeostasis of energy within the mitochondria. PPAR $\alpha$ gene Intron 7 variation is associated with the phenotype of human performance. Homozygous GG is more often found among athletes concerning muscular endurance. This study aims to investigate the association of PPAR $\alpha$ polymorphism with muscular endurance. Samples from buccal cells were collected from 77 boys (aged 11-16 years). PPAR $\alpha$ Intron 7 polymorphism was examined using PCR-RFLP with restriction enzyme TaqI. Meanwhile, the Curl-Up test has been performed to determine the muscular endurance of the subjects. The relationship between PPAR $\alpha$ Intron 7 polymorphism with muscular endurance was assessed by using Fisher's Exact test. The study found the genotype GG and GC of $97.4 \%$ and $2.6 \%$, respectively. Muscular endurance was shown among categories of poor $(66.2 \%)$ and fair (15.6\%). Statistical analysis established no association between PPAR $\alpha$ polymorphism with muscular endurance $(\mathrm{p}=0,564)$.

Keywords: PPAR $\alpha$ polymorphisms, muscular endurance, Curl-Up test
\end{abstract}

\section{INTRODUCTION}

Football is very popular in Indonesia, this can be seen from the enthusiasm of the Indonesian people in supporting the national team when competing. However, the Indonesian national team has not been able to show proud achievements in football at the international level, let alone win the FIFA world cup. Indonesian football in the future should focus on coaching young players.
Coaching soccer players does not only focus on training in playing football techniques but also on physical abilities. Physical ability depends on a combination of several environmental and genetic factors. Several genetic variants have important effects on the composition of the human body and metabolism, such as muscle endurance, muscle explosive power, strength, mass, and composition of muscle fibers, agility, 
neuromuscular coordination and even affect other phenotypes. ${ }^{1,2}$

The peroxisome proliferatoractivated receptor alpha gene (PPAR $\alpha$ ) located on chromosome 22 (22q12-q13.1) is a transcription factor that regulates fat metabolism, glucose, and energy homeostasis in the mitochondria which will be activated during a decrease in energy during exercise and in the type of exercise which is oriented towards muscular endurance. PPAR $\alpha$ gene expression is very high in tissues that metabolize fatty acids, especially in the liver, skeletal muscle and heart. PPAR $\alpha$ gene expression is also higher in type I muscle fibers (slowtwitch) than in type II muscle fibers (fast-twitch). Genetic variations that are often analyzed are located in intron 7 (G / C, rs4253778). ${ }^{3}$

The frequency of the $\mathrm{C}$ allele in the PPAR $\alpha$ gene was significantly more frequently found in soccer players than in untrained people and in school-age children in Russia compared to homozygous GG. ${ }^{1,4}$ Lithuanian male athletes with CC / GC genotype in the PPAR $\alpha$ gene had significantly greater muscle mass and muscle contraction strength than homozygous GG. While allele $\mathrm{C}$ was significantly found in the majority of athletes oriented to muscle explosive power compared to athletes oriented to aerobic or anaerobic mixed activities. $^{5}$

PPAR $\alpha$ G/C gene polymorphisms are associated with sports that are oriented to muscle endurance. This is evidenced by the relationship of the $G$ allele to the increase in fatty acid oxidation in skeletal muscles and an increase in the proportion of type I muscle fibers due to the more efficient use of oxygen during continuous muscle activity. ${ }^{3,6}$ Athletes who exercise endurance-oriented relatively have more type I muscle fibers than type II in the muscles that are trained. This allows muscle contractions to last for a long time. ${ }^{2,6,7}$

The purpose of this study was to determine the relationship between PPAR $\alpha$ gene variants and muscle endurance in soccer school students in Medan.

\section{METHODS}

This study uses a crosssectional study involving several soccer schools in Medan, including Sejati Pratama soccer school (SSB), Taman Setia Budi Indah SSB and the University of North Sumatra SSB. Approval of research ethics was obtained from the Ethics Commission of the Faculty of Medicine, the University of North Sumatra with Number No.496 / TGL / KEPK FK USU-RSUP HAM / 2016.

The total sample of the study was 77 people with male sex, aged 11-16 years old, doing routine exercise 3 times a week, and in good health, as evidenced by the results of physical examination.

Buccal cells are taken using a buccal brush, DNA isolation from each buccal cell sample is carried out at the USU Faculty of Medicine Integrated Laboratory. Materials used for DNA isolation include; PrestoTM Buccal Swab gDNA Extraction Kit (Geneaid), Proteinase $\mathrm{K}(100 \mu \mathrm{g} / \mathrm{mL}), 10 \mathrm{x}$ Tris-AcetateEDTA (TAE) Buffer (Vivantis). Measurement of DNA concentration and purity was carried out using a NanoPhotometer.

Amplification of the PPAR $\alpha$ G/C Intron 7 gene using Primary Forward-5 'ACA ATC ACT CCT 
TAA ATA TGG TGG 3' with a volume of $1.0 \mu \mathrm{L}$ and Primary Reverse-5 'AAG TAG GGA CGA ACA GGA CCA GTA 3' with volume 1, $0 \mu \mathrm{L}$. GoTaq (R) Green Master Mix (Promega, USA) uses a volume of $12.5 \mu \mathrm{L}$, DNA samples with a volume of $2.0 \mu \mathrm{L}$ and Nucleus Free Water $8.5 \mu \mathrm{L}$ to a volume of 25 $\mu \mathrm{L}$. The PCR program was conditioned with an initial denaturation stage at $95^{\circ} \mathrm{C}$ for 2 minutes, followed by 30 denaturation cycles for 30 seconds, annealing at $56{ }^{\circ} \mathrm{C}$ for 30 seconds and an extension stage at $72{ }^{\circ} \mathrm{C}$ for 30 seconds with the final extension stage at a temperature of $72{ }^{\circ} \mathrm{C}$ for 5 minutes. The PCR product was 5.0 $\mu \mathrm{L}$ incubated using the TaqI (Bioline) enzyme with a volume of $0.5 \mu \mathrm{L}, 10 \mathrm{x}$ TaqI buffer (with BSA) $1.0 \mu \mathrm{L}$, and Nucleus Free Water 3.5 $\mu \mathrm{L}$. This method results in a truncation of $266 \mathrm{bp}$ amplicon (GG) into two $\mathrm{C}$ allele fragments at $216 \mathrm{bp}$ and $50 \mathrm{bp}$. The RFLP-PCR product was incubated in a water bath at $65^{\circ} \mathrm{C}$ for 4 hours. Electrophoresis using Agarose (Bioline) with a concentration of $3 \%$ at a voltage of $80 \mathrm{~V}$ for 90 minutes, Hyperladder / Marker DNA $25 \mathrm{bp}$ (Bioline) with a volume of $5.0 \mu \mathrm{L}, 10 \mathrm{x}$ Tris-AcetateEDTA (TAE) Buffer (Vivantis),
Ethidium Bromide is used for coloring gene variations and visualized using a UV reader (UVITEC).

Muscle endurance checks are performed using the Curl-Up test. The number of Curl Ups that each subject can do will be interpreted. Interpretation of Curl-Up results is a very good category (above 90 percentile), good category (70-80 percentile), average category (50-60 percentile), less category (30-40 percentile) and very less category (below percentile) 20)

The statistical test used to determine the relationship between PPAR $\alpha$ G/C Intron 7 genotype variants and muscle endurance is the Fisher's Exact Test statistical analysis.

\section{RESULTS}

The research subjects were students of football school (SSB) aged 11-16 years, male sex, doing soccer training routinely 3 times a week, guided by a coach, with a healthy physical condition as evidenced by the results of physical examination.

Table 1 shows the percentage variation in the majority of GG genotypes found with the number of $\mathrm{G}$ alleles (97.4\%) compared to $\mathrm{C}$ alleles

$(2.6 \%)$.

Table 1. Distribution of PPAR $\alpha$ G / C Intron 7 Polymorphisms

\begin{tabular}{lcc}
\hline PPARa G/C Intron 7 gene polymorphism & Number & Percentages (\%) \\
\hline GG & 75 & 97.40 \\
GC & 2 & 2.60 \\
CC & 0 & 0.00 \\
G allele & 152 & 97.40 \\
C allele & 2 & 2.60 \\
Number of G and C alleles & 154 & \\
\hline
\end{tabular}


Table 2 shows that muscle endurance in the majority of soccer school children is very low in the genotype of GG by 50 people $(64.9 \%)$, but muscle endurance is very good for 2 people $(2.6 \%)$ and muscle endurance is good for 4 people $(5.2 \%)$.

Table 2. Bivariate analysis of PPARa G / C Intron 7 Gene Polymorphisms with Muscular Endurance

\begin{tabular}{|c|c|c|c|c|c|c|}
\hline \multirow{2}{*}{$\begin{array}{c}\text { PPARa GC } \\
\text { Genotype Intron } \\
7\end{array}$} & \multicolumn{5}{|c|}{ Muscle endurance } & \multirow[b]{2}{*}{ Nilai $p$} \\
\hline & $\begin{array}{c}\text { Excellent } \\
\text { n }(\%)\end{array}$ & $\begin{array}{l}\text { Good } \\
\text { n }(\%)\end{array}$ & $\begin{array}{c}\text { Average } \\
\text { n }(\%)\end{array}$ & $\begin{array}{c}\text { Below } \\
\text { average } \\
\text { n }(\%) \\
\end{array}$ & $\begin{array}{l}\text { Poor } \\
\text { n }(\%)\end{array}$ & \\
\hline GG & $2(2.6)$ & $4(5.2)$ & $8(10.4)$ & $11(14.3)$ & $50(64.9)$ & \\
\hline GC & 0 & 0 & 0 & $1(1.3)$ & $1(1.3)$ & $0.504^{\prime}$ \\
\hline
\end{tabular}

*Fisher's Exact test sign $<0.05$

Statistical analysis using Fisher's test (0.564) showed no significant relationship between PPAR $\alpha \mathrm{G} / \mathrm{C}$ Intron 7 gene polymorphisms and muscle endurance.

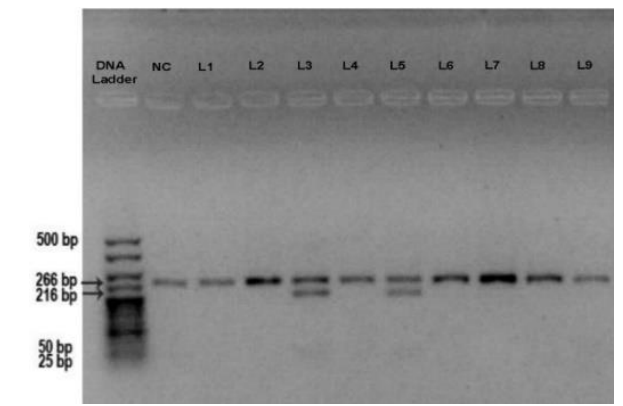

Figure 1. PCR-RFLP Electrophoresis Results of The PPARa G / C Intron 7 Gene Product (Lane L1,2,4,6,7,8 and 9: GG; Lane 3 and 5: GC).

\section{DISCUSSION}

Based on the results of this study it was stated that the GG genotype had the highest percentage (97.5\%) and GC genotype (2.6\%), while the CC genotype was not found in this study. Other results also state that the frequency of the GG genotype and PP allele G / C Intron 7 gene alleles was statistically higher found. In a study of Russian athletes oriented to muscle endurance, genotypes of GG (80.3\%), GC $(17.9 \%)$ and CC (1.8\%) were found. ${ }^{8}$
Research on children aged 11 years showed genotyping of GG $(75.6 \%)$, GC $(22.3 \%)$ and CC $(2.1 \%){ }^{9}$ Research on Lithuanian soccer players shows the genotypes of GG (63.3\%), GC (33.2\%) and CC $(3.5 \%) .{ }^{10}$ Research on professional Italian soccer players found genotypes of GG (48\%), GC (44.5\%) and CC $(7.5 \%) .{ }^{11}$ While research on Caucasian ethnicity showed genotyping of GG (33.17\%), GC $(46.91 \%)$ and CC (19.90\%). ${ }^{12}$ Then research on Israeli athletes obtained the results of genotyping GG $(5 \%)$, GC $(43 \%)$ and CC (67\%). ${ }^{13}$

In the results of this study, the muscle endurance of the majority of soccer school children is very low. But genetically it has supported having good muscular endurance. Based on the results of previous studies it has been stated that the GG genotype in intron 7 PPAR $\alpha$ genes is associated with muscle endurance. GG genotype subjects have lower biceps size and pushing strength compared to GC and $\mathrm{CC}$ genotypes. ${ }^{12} \mathrm{G}$ allele is associated with an increase in fatty acid oxidation and an increase in the number of types I muscle fibers 
(slow twitch) which contribute to muscle endurance in athletes and more efficient use of oxygen. Significantly the majority of $G$ alleles were found in Russian athletes oriented to muscular endurance compared to athletes oriented to muscle explosive power and homozygous GG was significantly higher found in type I muscle fibers compared to homozygous GC. ${ }^{8}$ Allele $\mathrm{C}$ in the PPAR $\alpha$ gene was found in a group of athletes oriented to a combination of endurance and muscular endurance compared to the general population, CC genotype was associated with increased muscle mass and greater muscle contraction, while GG genotype was associated with muscular endurance. ${ }^{5}$ The frequency of PPG $\alpha$ gene GG genotype is higher in endurance-oriented Israeli athletes. ${ }^{13} \mathrm{G}$ allele in rowing athletes was found to be more dominant than in untrained people. ${ }^{14}$ The majority of GG genotypes were also found in professional Italian soccer players compared to the control group. ${ }^{11}$

The low muscle endurance in soccer school children may be due to various factors, including the exercise factor. One type of exercise to increase muscle endurance that is recommended is a 60-second sit-up exercise. Regular sit-up exercises will help increase the strength and speed of abdominal muscle contraction and prevent fat accumulation. Another recommended exercise is running 100 meters. Long-distance running exercises (1000 meters) will increase cardiorespiratory endurance. With good endurance, soccer players will stay awake during the match. ${ }^{15}$ Muscle endurance training increases the use of non-plasma fatty acids and increases the oxidative ability of skeletal muscles through regulation of PPAR gene expression. ${ }^{4}$

Muscle endurance training for 6 weeks in adolescent athletes shows an increase in muscle endurance by $8-41 \%{ }^{16}$ While neck muscle endurance exercises for 12 weeks in swimming athletes provide a progressive increase in the time of muscle contraction and the number of exercise reps. ${ }^{17}$ Exercise programs that are carried out at a young age can increase muscle strength, muscle endurance, muscle burst strength, and balance. It also can improve body composition and motor skills. Thus a permanent training program is needed. ${ }^{18}$

Muscle endurance training for 6 weeks $\left(\mathrm{VO}_{2 \max } 60 \%-80 \%\right)$ is needed to stimulate an increase in PPAR $\alpha$ mRNA so that it will increase mitochondrial biogenesis. Increased PPAR $\alpha$ in type I muscle fibers causes an increase in the oxidative ability of fatty acids and insulin response. ${ }^{19}$ The composition of the type of muscle fibers is determined isoform myosin heavy chain (MHC). The percentage of MHC IIA is higher at the age of 15 years more than the age of 11-13 years. But the percentage of type I muscle fibers (slow twitch) is significantly lower at the age of 15 compared to ages 11-13 years. The high proportion of MHC IIA in muscle fibers indicates anaerobic adaptive response, muscular and aerobic explosive power, spontaneous muscular endurance to soccer training programs. Increased type IIA muscle fibers are associated with differences in exercise programs. $^{20}$ 


\section{CONCLUSIONS}

Based on the results of statistical analysis there is no relationship between PPAR $\alpha$ genotype variants and muscle endurance. But genetically, subjects have been supported to have good muscular endurance. Exercise factors, nutrition, and other genetic variants can also affect muscle endurance. Further research is recommended to examine the relationship of PPAR $\alpha$ gene variants to muscle fibers and their effect on fatty acid oxidation related to muscle endurance in femoris muscle. This kind of research has never been done in Indonesia.

\section{ACKNOWLEDGMENT}

The author thanks Dr.med. dr. Yahwardiah Siregar who facilitated buccal cell DNA isolation and PCRRFLP methods. Thanks also to Binayanti and Karin for collecting buccal samples and for the parents and Trainer of the Sejati Pratama Soccer School, Taman Setia Budi Indah, the University of North Sumatra for allowing soccer school children as research subjects.

\section{REFERENCES}

1. Ahmetov II, Fedotovskaya ON. Sports genomics: Current state of knowledge and future directions. Cell. Mol. Exerc. Physiol. 2012; 1: 1-25.

2. Leonska-Duniec A. Genetic research in modern sport. Centr. Eur. J. Sport. Sci. Med. 2013; 3: 19-26

3. Lopez-Leon S, Tuvblad C, Forero DA. Sports genetics: the PPARA gene and athletes' high ability in endurance sports. A systematic review and metaanalysis. Bio. Sport. 2016; 33: 3-6.

4. Ahmetov II, Egorova ES, Mustafina LJ. The PPARA gene polymorphism in team sports athletes. Centr. Eur. J. Sport. Sci. Med. 2013; 1: 1924.

5. Ginevičienè $\mathrm{V}$, Pranckevičienė E, Milašius K, Kučinskas V. Relating fitness phenotypes to genotypes in Lithuanian elite athletes. Acta Medica Lituanica. 2010; 17: 1-10.

6. Ahmetov II, Williams AG, Popov DV, Lyubaeva EV, Hakimullina AM, Fedotovskaya ON, et al. The combined impact of metabolic gene polymorphisms on elite endurance athlete status and related phenotypes. Hum. Genet. 2009 ;126(6): 751761.

7. Tural E, Kara N, Agaoglu SA, Elbistan M, Tasmektepligil MY, Imamoglu O. PPAR- $\alpha$ and PPARGC1A gene variants have strong effects on aerobic performance of Turkish elite endurance athletes. Mol. Biol. Rep. 2014; 41: 5799-5804.

8. Ahmetov II, Mozhayskaya IA, Flavell DM, Astratenkova IV, Komkova AI, Lyubaeva $\mathrm{EV}$, et al. PPAR $\alpha$ gene variation and physical performance in Russian athletes. Euro.J.App. Physiol. 2006; 97: 103-108.

9. Ahmetov II, Gavrilov DN, Astratenkova IV, Druzhevskaya AM, Malinin AV, Romanova EE, et al. The 
association of ACE, ACTN3 and PPARA gene variants with strength phenotypes in middle school-age children. J. Physiol. Sci. 2013; 63: 79-85.

10. Gineviciene V, Jakaitiene A, Tubelis L, Kucinskas V. Variation in the ACE, PPARGC1A and PPARA genes in Lithuanian football players. Euro. J. Sport. Sci. 2014; 14: 289-295.

11. Proia P, Bianco A, Schiera G, Saladino P, Contrò V, Caramazza G, et al. PPAR $\alpha$ gene variants as predicted performance-enhancing

polymorphisms in professional Italian soccer players. Open Access J. Sports. Med. 2014; 5:273278.

12. Ellis L, Collins C, Brown J, Pooley W. Is AGT The New Gene For Muscle Performance? An Analysis of AGT, ACTN3, PPARA and IGF2 on Athletic Performance, Muscle Size and Body Fat Percentage in Caucasian Resistance Training Males. J. Athl. Enhanc. 2017, 6.

13. Eynon N, Meckel Y, Sagiv M, Yamin C, Amir R, Goldhammer E, et al. Do PPARGC1A and PPAR $\alpha$ polymorphisms influence sprint or endurance phenotypes?. Scand. J. Med. Sci. Sport. 2010; 20: 145150.

14. Maciejewska A, Sawczuk M, Cięszczyk P. Variation in the PPARa gene in Polish rowers. J. Sci. Med. Sport. 2011; 14: 58-64.
15. Anwar S. Survei teknik dasar dan kondisi fisik pada siswa sekolah sepak bola (SSB) se kabupaten Demak tahun 2012. J. Phys. Educat. Sport. Health. Recreat. 2013: 2: 596-604

16. Granacher U, Schellbach J, Klein K, Prieske O, Baeyens JP, Muehlbauer T. Effects of core strength training using stable versus unstable surfaces on physical fitness in adolescents: a randomized controlled trial. BMC. Sports. Sci. Med. Rehabil. 2014; 6: 40-41.

17. Weston M, Hibbs AE, Thompson KG, Spears IR. Isolated core training improves sprint performance in national-level junior swimmers. Int. J. Sports. Physiol. Perform. 2015; 10:204-210.

18. Behm DG, Faigenbaum AD, Falk B, Klentrou P. Canadian Society for Exercise Physiology position paper: resistance training in children and adolescents. Appl. Physiol. Nutr. Metab. 2008; 33: 547-61.

19. Russell AP, Feilchenfeldt J, Schreiber S, Praz M, Crettenand A, Gobelet C, et al. Endurance training in humans leads to fiber typespecific increases in levels of peroxisome proliferatoractivated receptor- $\gamma$ coactivator-1 and peroxisome proliferator-activated receptor- $\alpha$ in skeletal muscle. Diabetes. 2003; 52 :28742881.

20. Metaxas TI, Mandroukas A, Vamvakoudis E, Kotoglou K, 
Ekblom B, Mandroukas $\mathrm{K}$. Muscle fiber characteristics, satellite cells and soccer performance in young athletes. J. Sports. Sci. Med. 2014;13: 493-501. 